\title{
IDEOLOGICAL COMPLEXES ON DISABILITY IN THE IBERIAN LITERARY TRADITION OF GALICIAN-PORTUGUESE SONGS
}

\author{
Ulisses Tadeu Vaz \\ De Oliveira
}

\section{(c) $(7) \Theta$}

Doi: https://doi.org/10.15517/rfl.v46i2.42437

URL: https://revistas.ucr.ac.cr/index.php/filyling/index 



\title{
IDEOLOGICAL COMPLEXES ON DISABILITY IN THE IBERIAN LITERARY TRADITION OF GALICIAN-PORTUGUESE SONGS
}

\author{
COMPLEJOS IDEOLÓGICOS SOBRE DISCAPACIDAD \\ EN LA TRADICIÓN LITERARIA DE LAS CANTIGAS \\ GALLEGO PORTUGUESAS
}

\section{Ulisses Tadeu Vaz De Oliveira}

\begin{abstract}
Literature has been especially important in the construction of human thought and development. From this perspective, ideology, as a contextual dimension of a higher order, gets into the literary text and, at the same time, becomes shaped by the genius of authors throughout the centuries. Therefore, when we face ideological social dilemmas, such as the emergence, change, perpetuation and consequences of prejudice, stereotyping and discrimination on disability in our society, it is natural to question the role of the literature in the formation of foundational ideological paradigms. This article intends to marry a literary analysis with the functional linguistic approach of Appraisal -dealing with the semantics of evaluation- in order to present an initial set of ideas of our literary tradition in Galician-Portuguese medieval songs. Research goals include: the identification of (mis) representations of disability in the corpus; the detection of ideology(ies) scaffolding prejudicial representations; and the determination of the role of Galician Portuguese songs in consolidating or strengthening this type of prejudice. Results revealed this body of art presenting a misrepresentation of disabled people that, ultimately, composed a corollary of ideological heritage that have influenced the Iberian and Western literary tradition until the present time.

Keywords: ideology; galician-portuguese songs; disability; prejudice; stereotype.
\end{abstract}

\section{RESUMEN}

La literatura ha sido especialmente importante en la construcción del pensamiento y el desarrollo humano. En esta perspectiva, la ideología -dimensión contextual de orden superior- entra en el texto literario y también se configura por el genio de los autores a lo largo de los siglos. Así, cuando enfrentamos dilemas sociales ideológicos, como el surgimiento, el cambio, la perpetuación y las consecuencias de prejuicios, estereotipos y discriminación sobre la discapacidad en nuestra sociedad, es natural cuestionar el papel de la literatura en la formación de paradigmas ideológicos fundamentales. Este artículo pretende unir un análisis literario con el enfoque lingüístico funcional de Appraisal -asociado a la semántica de la evaluación- para presentar un conjunto inicial de ideas de nuestra tradición literaria en las Canciones Medievales Gallego-Portuguesas. Los objetivos de esta investigación incluyen: la identificación de (mal)representaciones de discapacidad en el corpus; la detección de ideología(s) andamiando representaciones perjudiciales; y la determinación del papel de estas canciones en la consolidación o fortalecimiento de este tipo de prejuicios. Los resultados revelaron esta literatura presenta una tergiversación de las personas con discapacidad que, finalmente, compuso un corolario del patrimonio ideológico que ha influido en la tradición literaria ibérica y occidental hasta la actualidad.

Palabras clave: ideologia; canciones gallego-portuguesas; discapacidad; prejuicio; estereotipo.

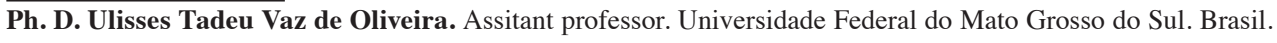
Correo electrónico: ulisvaz@gmail.com

Recepción: 02- 10- 19

Aceptación: 04- 02- 20 


\section{Introduction}

The history of the emergence, change, perpetuation and consequences of prejudice, stereotyping, and discrimination in our literary history dates back many years, long before the first texts were written in the contemporary languages. It is fair to say that intolerance has always been a big issue for the humankind to face, and for this reason, it has pervaded in world literature. Thus, more than a subject of analytical theories, literature may open readers' eyes to events and lifestyles they would perhaps not otherwise experience; and with those experiences, they come to understand ethical reflections that have erected a paradigm of consciousness of what one human being is able to do to another out of fear, hate, greed, and ignorance.

Some social groups are more constantly vulnerable to prejudice or misrepresentation likewise in literature, among them, disabled persons. As literature portrays societies, ideological complexes on disability are also reflected, constructed and criticized even in children's and youth literature, assuming stories are a portray of the reality and human psyche. According to Figueira (2000, p. 39):

Although little perceived, the collection of children's books bringing in their context issues related to disabilities is already varied. These books have been the object of study of The Social Psychology, and through certain "traps" in their narratives, they make up children's minds about prejudice and stereotype, even if it is unconsciously.

In this context, this article aims to look further into the beginnings of this sort of representations to present an initial set of ideological complexes on disability. In this case, I plunged into the Iberian literary tradition and its connections with the Western literary tradition. To that aim, the present study focuses on one of the first literary movement of Iberian Peninsula, the Galician-Portuguese literature. According to Ceschin (1998, p. 36), the troubadourism literary movement "built an ideology inspired by education, ethics, aesthetics, courtesy and chivalry [...] a tradition to which we are heirs". From this heritage, however, a central orientation of this investigation is the avoidance of an anachronistic point of view, since

our contemporary, modern attitudes influence how we try to analyse and interpret the past; that is, when faced with an impaired [p.ext. disabled] medieval person we would tend to judge their impairment, and how it might be disabling, by our culture's assumptions (Metzler, 2006, p. 6).

That said this article tries to marry a literary analysis with a functional theory that deals with the semantics of evaluation (Appraisal) to present an initial set of ideas on disability in our literary tradition of Galician-Portuguese medieval songs. The research goals are: (1) identifying (mis)representations of disability in the corpus; (2) detecting ideology(ies) scaffolding prejudicial representations; and (3) determining the role of Galician Portuguese songs in consolidating or strengthening this type of prejudice.

The analytical proposal of this study is supported by the theoretical and methodological framework of Appraisal (Martin, 2000) within the scope of the interpersonal metafunction of the Systemic-Functional Linguistics -developed by Halliday (1994)-, and which, according to Martin (2000, p. 144), aims to broaden the focus on the "semantics of evaluation" (i.e. how the interlocutors are feeling, the judgments they make and how they value the phenomena of their experience). Consequently, this proposal is considered highly efficient to determine the positioning adopted by authors when addressing opinions and point-of-views.

In the present case, focus is given to disabilities represented in the analysed songs and hypothesis of consolidation or strengthening of ideological paradigms therein. Hence, 
Appraisal's functional linguistic approach is able to reveal the (mis)representations of disability at that time on the Galician-Portuguese songs, as well as the presence of an ideological heritage that has also influenced Iberian authors and the Western literary tradition until the present time.

Next, before investigating the Galician-Portuguese literary tradition, I provide a depiction of key concepts in the spectre of disability studies.

\section{Prejudice and disability}

Prejudice does not seem to be part of the natural course of life. However, it is rather the product of the misuse of intelligence and willpower, rooted in deprecation and oppression of others, causing harmful consequences. According to Brown (2011, p. 27), prejudice can be regarded as "any attitude, emotion or behaviour towards members of a group, which directly or indirectly implies some negativity or antipathy towards that group". This type of feeling is also determined by the unavoidable historical dimension of the evaluation of the "other", many times registered in writers' accounts and perspectives. In this sense, it is paramount to understand how and when, and in which ways, the literature has presented characters and themes that portrayed persons with disabilities in a prejudicial way.

Disability, impairment and alterity in reference to different social groups cause some confusion among scholars who wrestle with the terminology. Hence, it seems necessary to shed some light on the issue and justify the use of "disability" in this study.

First, impairment -a more established concept- is considered the "deterioration in the functioning of a body part, organ, or system that can be temporary or permanent and can result from injury or disease" (Cambridge, n. d.). Consequently, impairment is much related to physical/health conditions which poses a crucial point of distinction to be borne in mind between impairment and disability (represented in the analysed songs). In the words of Metzler (2006, p. 9), “disability' is a cultural construction", having no "inherent meaning' outside of culture; one cannot therefore speak automatically of all impaired persons as disabled at all times, in all places".

In the same line of thought, Goodley (2016) finds appropriate the general use of disability to refer to this kind of wilful distortion of ethnicity, gender, religion, sexuality, social class, illness, origin, slavery, and segregation, in other words, aspects related to the deviation of what is culturally and socially standardized as "normal". Fanon (1993) is particularly bold in disconsidering "alterity" as a general term to the same purpose because there is the "nondisabled alterity", in other words, the non-disabled is alterity for the disabled: "alterity for the black man is the white man" (Fanon, 1993, p. 97).

Goodley (2016, p. 79) sees alterities as patterns related to "analyses of otherness and standards against which individuals are expected to judge themselves". In this spectrum, alterity is a possible condition of disabled people when the "big Other" is constituted through variants of normality ${ }^{1}$. The otherness standpoint is what better contrast alterity and disability, as in Campbell's $(2008,2009)$ studies where "ableism" is termed as a concept of alterity normativity.

1 The "big Other": "Cognitively, socially and emotionally able and competent. Biologically and psychologically stable, genetically sound and ontologically responsible. Normal sane, autonomous, selfsufficient, reasonable, law-abiding and economically viable. White, heterosexual. male, adult. Living in towns, global citizen of WENA" (Goodley, 2016, p. 79). [WENA - Western Europe \& North America]. 
The ableist-normativity investigated by the author (Campbell, 2008, p. 1) sets apart the "monstrous other" (disabled people) and the "extraordinary other" (the abled ones). Consequently, those assumptions prevent the adoption of alterity to fit the objectives of this study since it is a notion scaffolded on the premises of the otherness' point of view.

Another issue is imposed to this conceptualization: the specific context of the songs here examined: the medieval Iberian Peninsula. According to Metzler (2006),

\begin{abstract}
To an extent, one has to examine whether and how (modern) disability theories, which make the distinction between 'impairment' and 'disability', can be applied to the medieval period, for the simple reason that until now no other theoretical framework for a discussion of disability within a cultural context exists. [...] Hence it is possible to regard 'disability' as an emic condition, in that it is culturally constructed, and therefore culturally specific, and 'impairment' as an etic condition, in that it is biological and (apparently) transcultural.
\end{abstract}

Although Metzler builds an argument of applying both terms in different capacities to study medieval times, in the present study, I apply disability as a reference to contextually disregarded alterities reflected in the body, thought and behavior (see Albrecht, Seelman \& Bury, 2001) with power to marginalize, dispossess and flatten the experience of persons. This interpretation is based on the notion that

clearly, disabled people constitute a heterogeneous group within which there will be multifarious dealings with the world. [...] The alterity knows disabled people in deficient ways. Disabled people are their impairment. They are broken individuals. They lack development. They cannot do. They do not have the abilities to lead an independent life. The dominant Other threatens to create epistemic invalidation (Goodley, 2016, p. 80).

In Middle Ages, within the territory in which Galician Portuguese songs were produced, the disabled label fell upon persons like survivors of bubonic plague, diphtheria, and leprosy, maimed, blind, handicapped, sick and malformed people. A similar fate dawned socially deprived groups such as homosexuals, Jews, Muslims and converted persons who lived in disability conditions in some locations ${ }^{2}$.

\title{
3. The Galician-Portuguese songs and the literary tradition
}

The Galician-Portuguese language was spoken during the Middle Ages in regions of present-day Portugal and Galicia. According to some authors (for example, Sansone \& Furtado, 2014), modern Portuguese and Galician languages descend in part from GalicianPortuguese. It is largely considered one of the most prominent medieval peninsular languages due to its literary profusion, which later resulted in many contributions to Portuguese and Spanish languages. Galician-Portuguese was primarily used for literary purposes from the final years of the 12th century to roughly the middle of the 14th century in what are now Spain and Portugal and was, almost without exception, the language used for the composition of lyric poetry in several kingdoms, such as Galicia, Portugal, Leon and Castile (Oliveira, 1987). At the very least, there is no doubt that Portuguese literature blossomed from the Galician-Portuguese

2 Both sexual and religious orientations, highlighting homosexuals, Jews and Muslims, when approached by troubadours as disabilities, are themes absolutely deep and complex in the universe of GalicianPortuguese songs. Given this wide-ranging scope, I conceive that a specific analysis for each one of these themes is necessary. In this research, however, I provide a short depiction of the homosexuality misrepresentation in order to pair a culturally rooted disability (see Goodley, 2016) with impairment disability subthemes in the context. 
lyricism, which was considered the second most important literary movement during the European Early Middle Ages ${ }^{3}$. Such literature flourished during the period of about 150 years.

The Iberian troubadours' art is compiled in four great songbooks (the four extant manuscripts of the Cantigas de Santa Maria, the Cancioneiro da Ajuda, the Cancioneiro da Biblioteca Nacional, and the Cancioneiro da Vaticana); in them, there are about 1680 handwritten songs of about 187 troubadours and jongleurs, from genres of cantiga de amor, cantiga de amigo, cantiga de escárnio and cantiga de maldizer ${ }^{4}$.

Researching culture and society of that time through the Galician-Portuguese lyricism is a matter of the uttermost importance. A number of studies analyzed how Western literature was in general affected by the Galician-Portuguese lyricism ${ }^{5}$. Inside the Peninsula, the heritage of this literature is evident by how language and literature evolved from that. Therefore, beyond linguistic features, social, cultural and ideological aspects were first shaped and portrayed in this Iberian germinal body of art. With regard to our object of analysis, some songs are significant due to the heralds of representation of disabilities (Table 1$)^{6}$.

3 Sequeira (1959), as well as many other scholars, conceives the Occitan literature as the most important literary movement in Early Middle Ages. It began in the 11th and 12th centuries in different centers, gradually expanding in much of southern France and then in Catalonia, Galicia, Castile, Portugal and northern Italy. Occitan literature was the first literature in a Romance language that inspired the rise of vernacular literature throughout medieval Europe (Spina, 1997).

$4 \quad$ A good review of these genres can be found in Miguélez-Carballeira (2014).

5 Chaucer, Master of the English literature, had real interest in the Iberian Peninsula with mentions to "Spain" or "Spanish" things in ten stories of the Canterbury Tales (Yeager, 2007, pp. 194-195). He also mentions Petrus Alfonsi in the Tale of Melibee and provides a detailed account of Pedro I's death in the Monk's Tale (Rodríguez, 2017, p. 1). Hume (1905) sees influences of Galician-Portuguese literature in authors like Shakespeare and Donne.

6 Galician-Portuguese songs were untitled. Scholars, therefore, usually use their first verse as a title of identification, or their numbers in the songbooks they are found. For example, on the column References in Table 1, the song "Em preito que Dom Foam há," appears in two songbooks (codices) and it is also identified as B 1303 (Cancioneiro da Biblioteca Nacional, number 1303) and V 908 (Cancioneiro da Vaticana, number 908). 
Table 1. Disability subthemes: disability and impairment

\begin{tabular}{|c|c|c|c|}
\hline Subthemes & $\begin{array}{l}\text { Number } \\
\text { of songs in } \\
\text { the corpus }\end{array}$ & Authors & References \\
\hline $\begin{array}{l}\text { Mobility, visual } \\
\text { and hearing } \\
\text { impairment }\end{array}$ & 9 & $\begin{array}{l}\text { Estevam da Guarda (1 and 2) } \\
\text { João Airas de Santiago ( } 3 \text { ) } \\
\text { Rui Queimado (4 and 5) } \\
\text { D. Dinis (6 and } 7) \\
\text { João Soares Coelho (8 and 9) }\end{array}$ & $\begin{array}{l}\text { (1) "Em preito que Dom Foam há," } \\
\text { (2) "Meu dano fiz por tal juiz } \\
\text { pedir," } \\
\text { (3) "Dizem, senhor, que nom hei eu } \\
\text { poder," } \\
\text { (4) "Dom Estêvam, em } \\
\text { grand'entençom," } \\
\text { (5) "Dom Marco, vej'eu muito } \\
\text { queixar," } \\
\text { (6) “Ou é Meliom Garcia queixoso," } \\
\text { (7) “Tant'é Meliom pecador," } \\
\text { (8) "Dom Estêvam, que Lhi nom } \\
\text { gradecedes," } \\
\text { (9) "Quem diz de Dom 'Stêvam que } \\
\text { nom vê bem," }\end{array}$ \\
\hline $\begin{array}{l}\text { Disability through } \\
\text { various diseases or } \\
\text { physical-behavioral } \\
\text { aspects }\end{array}$ & 6 & $\begin{array}{l}\text { Afonso X (10 and 11) } \\
\text { Pero Garcia Burgalês (12) } \\
\text { Pero Garcia de Ambroa (13) } \\
\text { D. Dinis (14) } \\
\text { Estêvão Fernandes Barreto } \\
\text { (15) } \\
\text { Fernão Garcia Esgaravunha } \\
\text { (16) }\end{array}$ & $\begin{array}{l}\text { (10) "Ao daiam de Cález eu achei," } \\
\text { (11) "Domingas Eanes houve sa } \\
\text { baralha," } \\
\text { (12) "D'ũa cousa sõo maravilhado," } \\
\text { (13) "De Pero Bõo and'ora } \\
\text { espantado," } \\
\text { (14) "Disse-m'hoj'um cavaleiro," } \\
\text { (15) "Estevam Eanes, por Deus } \\
\text { mandade,"; } \\
\text { (16) "Nenguem-mim, que vistes mal } \\
\text { doente," }\end{array}$ \\
\hline
\end{tabular}

Source: Author.

In Table 2, I present detailed information about Galician-Portuguese songs that deal with disability-related (sub)themes. B and V are acronyms for, respectively, the Cancioneiro da Biblioteca Nacional, edition of Machado \& Machado (1949) and the Cancioneiro da Vaticana, edition of Braga (1878) ${ }^{7}$. Keywords in bold specify meanings associated with disability

7 In this article, the original text of songs in Galician-Portuguese language is maintained in examples and excerpts. Both of the aforementioned editions are largely considered problematic and have been largely revised for renowed philologists (for example, Lanciani, Tavani \& Gaspar 1995; Lopes, 1998). Hence, the analyzed songs will be followed by a critical apparatus and paraphrased in footnotes. 
Table 2. Disability in Galician-Portuguese songs

\begin{tabular}{|c|c|c|c|c|}
\hline Author & Source & Theme & $\begin{array}{l}\text { Specific theme } \\
\text { (disability) }\end{array}$ & Excerpt \\
\hline $\begin{array}{l}\text { Estevam da } \\
\text { Guarda }\end{array}$ & $\begin{array}{l}\text { B } 1303, \\
\text { V } 908\end{array}$ & $\begin{array}{l}\text { Satire targeting a } \\
\text { judge who, in addition } \\
\text { to being inept, was } \\
\text { lame. }\end{array}$ & $\begin{array}{l}\text { Mobility disability. } \\
\text { There's an ambiguity } \\
\text { centered on the verb } \\
\text { "decaer" - (a) to lose a } \\
\text { lawsuit and (b) to fall, } \\
\text { to lose balance. }\end{array}$ & $\begin{array}{l}\text { Rubric: "Esta cantiga de } \\
\text { cima foi feita a um meestre } \\
\text { de leis, que era manco d" } \\
\tilde{u} \text { a perna e sopegava dela } \\
\text { muito" } \\
\text { v. } 20,21 \\
\text { e quem esto vir, des ali, / } \\
\text { por mal andante o terrá. }\end{array}$ \\
\hline $\begin{array}{l}\text { Estevam da } \\
\text { Guarda }\end{array}$ & $\begin{array}{l}\text { B } 1305, \\
\text { V } 910\end{array}$ & $\begin{array}{l}\text { This song makes fun } \\
\text { of a deaf (or with } \\
\text { hearing impairment) } \\
\text { judge, playing with } \\
\text { the mistake that the } \\
\text { situation allows: that } \\
\text { of not being able / } \\
\text { not wanting to hear } \\
\text { complaints. }\end{array}$ & $\begin{array}{l}\text { A judge with a } \\
\text { degree of hearing } \\
\text { impairment. } \\
\text { It is uncertain if the } \\
\text { cause was real or a } \\
\text { made-up motif for the } \\
\text { satire. }\end{array}$ & $\begin{array}{l}\text { Rubric: "Esta cantiga foi } \\
\text { feita a um juiz que nom } \\
\text { ouvia bem" } \\
\text { v. } 11 \\
\text { pero lhe mandem, nunca } \\
\text { m'oirá; }\end{array}$ \\
\hline $\begin{array}{l}\text { Rui } \\
\text { Queimado }\end{array}$ & $\begin{array}{l}\text { B } 944, \\
\text { V } 532\end{array}$ & $\begin{array}{l}\text { Satire and praise to } \\
\text { the troubadour's own } \\
\text { wife. }\end{array}$ & $\begin{array}{l}\text { João Airas scorns his } \\
\text { own myopia: "I see } \\
\text { badly, but when I see } \\
\text { you, I see well." }\end{array}$ & $\begin{array}{l}\text { v. } 8,12 \\
\text { e dizem que nom vejo bem, } \\
\text { senhor, / } \\
\text { pois eu vos vejo, muito vejo } \\
\text { bem. }\end{array}$ \\
\hline $\begin{array}{l}\text { Rui } \\
\text { Queimado }\end{array}$ & $\begin{array}{l}\text { B } 1388, \\
\text { V } 997\end{array}$ & $\begin{array}{l}\text { This one deals } \\
\text { with the subject of } \\
\text { myopia or blindness: } \\
\text { complaint of a certain } \\
\text { D. Marco a Dom } \\
\text { Estêvam. Resende } \\
\text { de Oliveira (1993a) } \\
\text { believes that, by } \\
\text { reference to D. Marco, } \\
\text { this Dom Estêvam } \\
\text { should not be D. } \\
\text { Estêvão Anes whom } \\
\text { was the subject of } \\
\text { a group of songs } \\
\text { that also addressed } \\
\text { disabilities. }\end{array}$ & $\begin{array}{l}\text { Song emphasizes the } \\
\text { myopia or blindness of } \\
\text { D. Estevam. }\end{array}$ & $\begin{array}{l}\text { v. } 3,4,5 \\
\text { que, pero foi mui mal } \\
\text { doent'aqui, / que vos nunca } \\
\text { quisestes trabalhar / de o } \\
\text { veer, nen'o vistes; mais bem }\end{array}$ \\
\hline $\begin{array}{l}\text { Rui } \\
\text { Queimado }\end{array}$ & $\begin{array}{l}\text { B } 1386, \\
\text { V } 995\end{array}$ & $\begin{array}{l}\text { The same theme of } \\
\text { the previous one. }\end{array}$ & $\begin{array}{l}\text { Another song targeting } \\
\text { this D. Estevam and his } \\
\text { condition of myopia or } \\
\text { blindness. }\end{array}$ & $\begin{array}{l}\text { v. } 3,4 \\
\text { oí dizer por vós que a feitol } \\
\text { sodes cego; mais dix'eu que } \\
\text { mui bem }\end{array}$ \\
\hline
\end{tabular}




\begin{tabular}{|c|c|c|c|c|}
\hline D. Dinis & В 1533 & $\begin{array}{l}\text { King D. Dinis - a } \\
\text { young man at the time } \\
\text { - word tricks "girls" } \\
\text { (Galician-Portuguese } \\
\text { reference to the idiom } \\
\text { "apple of someone's } \\
\text { eye" is "girl of } \\
\text { someone's eye") } \\
\text { and "catar" (see) in } \\
\text { allusion to Meliom } \\
\text { Garcia's blindness. }\end{array}$ & $\begin{array}{l}\text { Lapa (1965) connects } \\
\text { this song to the next } \\
\text { one in B (1534) in } \\
\text { order to interpret the } \\
\text { wordplay that mocks } \\
\text { Meliom Garcia's } \\
\text { blindness / myopia. }\end{array}$ & $\begin{array}{l}\text { v. } 3,4 \\
\text { escontra duas meninhas que } \\
\text { trage, } \\
\text { contra que nom cata bem } \\
\text { nem fremoso: }\end{array}$ \\
\hline D. Dinis & В 1534 & $\begin{array}{l}\text { The same theme } \\
\text { of the previous one } \\
(1533) \text {. }\end{array}$ & $\begin{array}{l}\text { Due to blindness, } \\
\text { Meliom Garcia is } \\
\text { unable to "see the face } \\
\text { of God". }\end{array}$ & $\begin{array}{l}\text { v. } 13,14 \\
\text { que jamais nunca veerá } \\
\text { em nẽum temp'a face de } \\
\text { Deus. }\end{array}$ \\
\hline $\begin{array}{l}\text { João Soares } \\
\text { Coelho }\end{array}$ & $\begin{array}{l}\mathrm{V} 1014 \\
\text { bis }\end{array}$ & $\begin{array}{l}\text { Satire against a } \\
\text { certain D. Estêvão } \\
\text { and based on a } \\
\text { misunderstanding } \\
\text { about his visual } \\
\text { impairment. This } \\
\text { theme is coupled } \\
\text { with allusions } \\
\text { to homosexual } \\
\text { practices. This song, } \\
\text { and the following } \\
\text { from Coelho, is } \\
\text { part of a cycle of } \\
\text { songs against this } \\
\text { character, to whom } \\
\text { other troubadours } \\
\text { also dedicate songs. } \\
\text { From Coelho as well, } \\
\text { song V 1014 mocks } \\
\text { D. Estêvão, but it } \\
\text { is incomplete (only } \\
6 \text { verses) and does } \\
\text { not refer directly to } \\
\text { disability issues. }\end{array}$ & $\begin{array}{l}\text { D. Estêvão is mocked } \\
\text { by some degree of } \\
\text { visual impairment and } \\
\text { allusions to homosexual } \\
\text { practices. }\end{array}$ & $\begin{array}{l}\text { v. } 3,4 \\
\text { e como faz de vós haver } \\
\text { sabor / } \\
\text { os que vos vêem, que vós } \\
\text { nom veedes? }\end{array}$ \\
\hline $\begin{array}{l}\text { João Soares } \\
\text { Coelho }\end{array}$ & V 1015 & $\begin{array}{l}\text { The same theme of } \\
\text { the previous one. }\end{array}$ & $\begin{array}{l}\text { Mockery about the } \\
\text { blindness and "falls" } \\
\text { of D. Estêvão. The } \\
\text { expression "fall well" } \\
\text { imply a moral sense. }\end{array}$ & $\begin{array}{l}\text { v. } 13,14 \\
\text { E quem lho diz, sei que lhe } \\
\text { nom diría/ } \\
\text { ca vêe mal, se migo } \\
\text { falass'ante, }\end{array}$ \\
\hline Affonso X & $\begin{array}{l}\text { B } 493, \\
\text { V } 76\end{array}$ & $\begin{array}{l}\text { Strong attack on } \\
\text { the dean of Cadiz } \\
\text { regarding his taste } \\
\text { for erotic (Arab) } \\
\text { books, coupled with } \\
\text { his penchant for } \\
\text { witchcraft. }\end{array}$ & $\begin{array}{l}\text { Accused of being a } \\
\text { sorcerer and making } \\
\text { miracle cures to } \\
\text { specific diseases (in } \\
\text { exchange for sexual } \\
\text { favors). }\end{array}$ & $\begin{array}{l}\text { v. } 27,28 \\
\text { assi a fode per arte e per } \\
\text { sem, / } \\
\text { que saca dela o demo } \\
\text { malvaz. }\end{array}$ \\
\hline
\end{tabular}




\begin{tabular}{|c|c|c|c|c|}
\hline Afonso X & $\begin{array}{l}\text { B } 495, \\
\text { V } 78\end{array}$ & $\begin{array}{l}\text { Alfonso X, byname } \\
\text { Alfonso the Wise, } \\
\text { or the Learned, } \\
\text { satirizes a soldadesca } \\
\text { (Domingas Eanes) } \\
\text { who would have } \\
\text { been wounded by } \\
\text { the tragazeite (small } \\
\text { spear) of a Moorish } \\
\text { knight in battle. } \\
\text { Doctors could not } \\
\text { close the wound. }\end{array}$ & $\begin{array}{l}\text { Philologists believe it } \\
\text { is true that Domingas } \\
\text { Eanes' wound was } \\
\text { apparent. According } \\
\text { to Resende de Oliveira } \\
\text { (1993a), it is believed } \\
\text { that the fistulas caused } \\
\text { by the wound were } \\
\text { associated with some } \\
\text { venereal disease. }\end{array}$ & $\begin{array}{l}\text { v. } 28 \\
\text { e por en muit'há que é } \\
\text { fistolada. }\end{array}$ \\
\hline $\begin{array}{l}\text { Pero Garcia } \\
\text { Burgalês }\end{array}$ & $\begin{array}{l}\text { B } 1372, \\
\text { V } 980\end{array}$ & $\begin{array}{l}\text { Composition about } \\
\text { the death of a certain } \\
\text { Pedro Bom (unknown } \\
\text { identity). }\end{array}$ & $\begin{array}{l}\text { Satire lies in a kind of } \\
\text { disease that caused him } \\
\text { intestinal gas. }\end{array}$ & $\begin{array}{l}\text { v. } 5,6 \\
\text { e bem manceb'assaz pera } \\
\text { viver, / e foi doent'e nom se } \\
\text { confessou, }\end{array}$ \\
\hline $\begin{array}{l}\text { Pero Garcia } \\
\text { de Ambroa }\end{array}$ & В 1575 & $\begin{array}{l}\text { Same theme of the } \\
\text { previous one: the } \\
\text { death of a certain } \\
\text { Pedro Bom. }\end{array}$ & $\begin{array}{l}\text { Word tricks with the } \\
\text { sense of the verb peer: } \\
\text { fart / give the last } \\
\text { breath. }\end{array}$ & $\begin{array}{l}\text { v. } 7,14 \\
\text { e, ante luz, acharom-no } \\
\text { peideiro / já del mazela } \\
\text { nunca prenderia! }\end{array}$ \\
\hline D. Dinis & В 1540 & $\begin{array}{l}\text { Mockery to a knight } \\
\text { accused of slandering } \\
\text { and bad-mouthing. }\end{array}$ & $\begin{array}{l}\text { A sick knight is forced } \\
\text { to swallow a bitter herb } \\
\text { (lorbaga) as a laxative } \\
\text { due to a disease. }\end{array}$ & $\begin{array}{l}\text { v. } 15,16 \\
\text { mui doent'e mui nojoso / } \\
\text { e com medo per si caga, }\end{array}$ \\
\hline $\begin{array}{l}\text { Estêvão } \\
\text { Fernandes } \\
\text { Barreto }\end{array}$ & $\begin{array}{l}\text { B } 1611, \\
\text { V } 1144 \\
(\mathrm{~V} \\
1611)\end{array}$ & $\begin{array}{l}\text { Songs' rubric usually } \\
\text { explain the context. } \\
\text { Here, a supposedly } \\
\text { leper knight was } \\
\text { being chased by } \\
\text { another. }\end{array}$ & $\begin{array}{l}\text { This song is the only } \\
\text { reference to the leprosy } \\
\text { found in the Galician- } \\
\text { Portuguese songbooks. }\end{array}$ & $\begin{array}{l}\text { Rubric: "Esta cantiga de } \\
\text { cima fez Stevam Fernándiz } \\
\text { Barreto a um cavaleiro } \\
\text { que era gafo e morava em } \\
\text { Santarém; e soem a ir em } \\
\text { romaria a Santa Maria; aa } \\
\text { mão dereita do caminho } \\
\text { está logo a Triindade, e } \\
\text { estava logo a gafaria a par } \\
\text { dela." }\end{array}$ \\
\hline $\begin{array}{l}\text { Fernão } \\
\text { Garcia } \\
\text { Esgaravunha }\end{array}$ & B 1510 & $\begin{array}{l}\text { According to Lapa } \\
\text { (1970), this song } \\
\text { describes how this } \\
\text { troubadour brags } \\
\text { himself about having } \\
\text { healed from a serious } \\
\text { illness, namely } \\
\text { Nenguem-mim (slang). }\end{array}$ & $\begin{array}{l}\text { Such serious illness } \\
\text { seems to be just an } \\
\text { irony. Lapa (1965) } \\
\text { conceives it as a relief } \\
\text { from intestinal gas, } \\
\text { considering the context } \\
\text { and the "patient's" } \\
\text { desire for starting to } \\
\text { drink again. }\end{array}$ & $\begin{array}{l}\text { v. } 1,13 \\
\text { Nenguem-mim, que vistes } \\
\text { mal doente / } \\
\text { estornudou tres peidos e } \\
\text { guariu }\end{array}$ \\
\hline
\end{tabular}

Source: Author. Editions of excerpts: Machado \& Machado (1949) and Braga (1878)

Disabled individuals portrayed in Table 2 are mostly grouped in minorities, and the history of violence against these groups in the medieval Iberian Peninsula is multifarious, controversial and locally varied. In his accounts focusing on the religious minorities, Nirenberg (2015) insists on the necessity of separation of "discourse and agency", in a sense that audiences have been continuously led to ignore this dissention in order to conceive the presence of discourses of intolerance as a proof of a large-scaled intolerance. Moreover, the long-history 
and the general common sense interpretation of violence in medieval times reflect modern-life fears and blurs the notion that "the positive and the negative were inseparable" in medieval accounts. Nirenberg (2015, p. XV) interprets that "how we choose to classify those gestures [of violence] often depends on what questions we feel most urgent, what futures we must fear". That said, the discourses present in the themes and verses of the songs (referred in Table 2) parallel the mocking sarcasm of these song battles to a few negative discourses present in the medieval times, when ethical encoded values against minorities were, in some areas, a long way from what is mostly conceived appropriate in modern life. According to Le Goff (1986), this positive and negative dichotomy was ingrained in the feudal model and was reflected in the social and political medieval organizations. According to him,

The medieval society was more than many others, a society of oppositions and, if it had refused doctrinal Manichaeism, it practiced a practical Manichaeism through oppositions of the good/bad type, or of the superior/ inferior type. Christianity was thus often represented by binary schemes, by antithetical pairs (Le Goff, 1986, p. 12).

In addition to the antithetical pairs of religious backgrounds that polarized social groups, some present-day paradigms were built within civil society, among them, those which marginalized individuals who presented disabilities, such as social-behavioural alterities in disagreement with the "big Other" or impairment (deficiencies, ophthalmological diseases, leprosy, venereal diseases, etc.). In Middle Ages, as represented in the Galician Portuguese songs, given the fact that the medicine had not yet been established as a science, people experiencing disabilities had extreme difficulty in surviving and inserting themselves socially. Early Middle Ages registered poor levels of life expectancy; families could abandon a child when they felt unprepared to raise them and, in some severe cases, persons were let die and left without food simply because of a disability or related condition (Major, 1954).

Life in Iberian Peninsula was tough in some locations. In some areas, a continuous battlefield was part of people's everyday life, especially during the period when the northern Christian kingdoms battled back and forth with Arab states from Al-Andalus. In the face of this situation, a particularly critical social effect occurred in cities, where many men did not return from wars, or returned mutilated, disabled, handicapped, blind or sick. According to Ceschin (2004), because of the constant battles during seasons of invasions, most Iberian medieval cities were greatly populated by women, elderly and sick people. Street-level informal activities and begging were a frequent alternative; primarily after the growth of mendicant orders (Figure 1) ${ }^{8}$. At the time, it represented a huge problem to handle, mainly if kings and city administrators followed what Aristotle stated centuries earlier in his Politics: "as to the exposure and rearing of children, let there be a law that no deformed child shall live" (Aristotle in Reeve, 1998).

$8 \quad$ Christian religious orders that have adopted a lifestyle of poverty, traveling, and living in urban areas for purposes of preaching, evangelism, and ministry, especially to the poor (Tiron, 1848). 


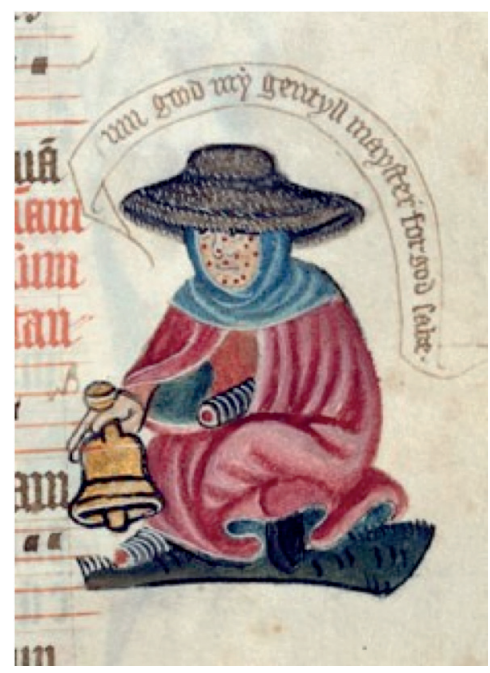

Figure 1. A begging leper

Source: British Library - Miniature from 1425 - MS Lansdowne 451, fo 127r

Living in disability was, in some cases, the best-case scenario. As Herculano (2014) chronicles, besides successive plagues and epidemics in Iberian Peninsula, cannibalism and corpses in putrefaction were day-to-day scenes during sieges. Oftentimes, invaders and royal representatives executed the sick, maimed and disabled. On this subject, it is appropriate to issue certain caveats here. The story of misrepresentation and suffering of disabled ones is "one story" of the medieval Iberian Peninsula, but not the single one. In her remarkable speech for TED conferences about her experience being stereotyped as a Nigerian writer, Adichie well summarizes that there is never a single story about anyone, in any time; and she maligns on the insistence of single stories about persons and places.

All of these stories make me who I am. But to insist on only these negative stories is to flatten my experience, and to overlook the many other stories that formed me. The single story creates stereotypes. And the problem with stereotypes is not that they are untrue, but that they are incomplete. They make one story become the only story (Adichie, 2009, n. p.).

Adichie's rationale hinders the biased or incomplete analysis of discourses and ideologies of minorities, as well as prevents analysts from fouling on the insistence of stereotyping as the "one and only" story about any social group. The medieval context of the songs under the microscope here offers a degree of complication in finding "other" stories. Cultural distance of societies and the credibility of sources are among the reasons raised by Le Goff (1982, p. X) to opt for a more balanced approach, namely "another Middle Ages". According to him, "a Middle Ages of the depths, as it were, would not subscribe to either the traditional myth of a dark age or the myth of a gilded age which some people today would like to substitute for it".

Despite the application of this "another Middle Ages" approach, however, people in the disability condition in medieval times were, more often than not, grouped on a "dark ages" spectre with the impaired persons in a more vulnerable situation (Metzler, 2006). For Lawson (2019, p. 2), "the impaired were universally marginalized across medieval Europe". 
There was also an overwhelming influence of religion in the medieval context, particularly Christianity, which escalated the contradictory notions of impairment as effect of sins and as a means of penitence?

Therefore, on a large scale, disabled came to mean a person who lived under the stigma of abandonment, in the dark side of the medieval society. Galician-Portuguese songbooks, furthermore, record this stereotyping attitude by, for example, anthroponyms. The onomastic indicates, albeit in a reduced number, aliases and pseudonyms based on disability identities for individuals. For Vivas \& Oliveira-Leitão (2008), "a nickname, by its very nature, can serve to enhance or denigrate one's image (from adjectives like ledo or loução, to others not as favourable as stutter, bald or old)". Richards (2000) points to the regularity of the anthroponym "the leper" in medieval England. The author says, "having leprosy meant living a life outside of society. When traveling through a town, people with leprosy were required to ring a bell, alerting others to their presence" (Richards, 2000, p. 24). In Iberian Peninsula, context of the Galician-Portuguese songs, a similar approach is adopted (as represented in song B 1611 - Estêvão Fernandes Barreto), inasmuch as Ruy Diaz de Bivar ("El Cid") founded the first leprosarium in Europe, in 1067, with a dual function of treating the patients and keeping them away of others.

Later, I present a more detailed analysis of two songs from Table 2, one of the Portuguese troubadours Estevão da Guarda ${ }^{10}$ and another of the troubadour Estêvão Fernandes Barreto $^{11}$. This way, I intend to evince underlying traces of the ideology within the disability

$9 \quad$ Examples of narratives and authors reflecting this line of thought: ocular infirmity in Fancis of Assisi "approaching reunion with Christ in death" (Wells, 2016), Richard III's disfigured body (Comber, 2016), and, in Southern France (1321), the heresy of lepers plotting to poison wells and infect the entire country with leprosy, which was used as argument for King Philip V to arrest lepers and put them on trial for treason (Kiple, 1999).

10 According to Oliveira (1993a), he is a Portuguese troubadour active in the final period of GalicianPortuguese poetry movement. Estêvão da Guarda must have been born around 1280, most probably in Guarda, as his nickname indicates. In 1299, we found him already in the court of D. Dinis, performing the functions of scrivener. In the following years, and especially after 1314, his gradual proximity to the king, to whom he recalls "vassal", is proven by: (1) a number of documents that he signs on D. Dinis' behalf, (2) the positions of eichão and escanção-mor he performed; and (3) royal donations and blessings on him in pledge of his fidelity and good service - and which contributed to the fortune he accumulated. Pizarro (1999, p. 424) claims that, after D. Dinis passed away, although his name appears more sporadically, Estêvão da Guarda continues to be mentioned as a royal counselor and procurator for Iberian affairs of Afonso IV. As part of his satirical compositions may be dated from this period, his troubadour activity certainly begun earlier -in the reign of King D. Dinis- and must have lasted until the middle of the fourteenth century. Still alive in 1362, he died a little before April 1364 (already in Dom Pedro I reign), and was buried in the Monastery of São Vicente de Fora (Oliveira, 1993a).

11 Portuguese troubadour, active at the end of the thirteenth century. Originally from a family of infanções (minor noble title) from Entre-Douro-e-Minho region. Estêvão Fernandes was the son of Fernão Gomes Barreto -knight in the court of Alfonso III- and Sancha Pais de Alvarenga, being cousin of the also troubadours João Velho and Fernão Rodrigues Redondo. Her mother-in-law, D. Maria Rodrigues Chacim, had a documented extramarital relationship with King D. Dinis. According to the nobility book Nobiliário do Conde D. Pedro (26S5), Estêvão Fernandes Barreto married in Santarém with Joana Esteves. It is precisely in Santarém that the troubadour is for the last time documented, in 1294, as a witness to a D. Dinis' donation to the village council. His only preserved song points out to the very same space-time coordinates. 
paradigm in this historical specificity. To that aim, following, I discuss the theoretical and methodological model applied in this proposal, the Appraisal theory (Martin, 2000) and its relevance as a model to investigate ideological meanings.

\section{Appraisal and the critical analysis of ideology}

Before discussing the basis of the theoretical methodological framework adopted in this study, namely Appraisal, considering that prejudice, stereotyping and discrimination on disability have an ideological foundation, it is necessary to provide a better understanding of the perspective adopted in this research regarding ideology and its ramifications in text since "all texts [...] are affected by some ideology or other" (Banks, 2009, p. 39).

Althusser recovers and discusses the social-historical basis of ideology from Marx to establish a more operational notion embracing the cognitive unfolding of ideologies in "world outlooks". He postulates that "ideology is a 'representation' of the imaginary relationship of individuals to their real condition of existence" ([1970] 2009, p. 100). This relationship of individuals in their real condition of existence (and living in society), is better defined as "social practices" by Van Dijk (2006, p. 15) to whom ideologies are "sociocognitively defined as social representations of social groups, and more specifically, as 'axiomatic' principles of such representations". Ideologies sustain social groups' self-images and organize their "identity, actions, aims, norm and values and resources, as well as its relations to other social groups" (Van Dijk, 2006, p. 15).

The aforementioned group-based approach is what potentializes prejudice encapsulated in ideologies harmful for societies. Naturally, such encoded ideologies were also present in the corpus of this research. According to Van Dijk, social representations are never individually rooted, as he succinctly points out: ideologies are the "basis of the social representations shared by members of a group" (Van Dijk, 1998, p. 8). Sociopolitical or sociocultural ideologies are intertwined with discourse (Li, 2010; Van Dijk, 2002), this way, a basic premise of Critical Discourse Analysis is that language in use implies ideological meanings while restraints the use of language and meanings involved (Fowler, 2013).

According to Fuoli (2015), analyses on the tradition of Systemic-Functional Linguistics (SFL) focusing on investigating the ideological implications for patterns in discourse are conceived appropriate when the issue of ideology is at stake. In this sense, at the core of the interpersonal metafunction of SFL, Appraisal is a discursive-semantic system that provides a model to investigate evaluation in texts and its cumulative semantic patterning. Devised by Martin (2000) and developed by collaborators (Iedema, Feez \& White, 1994; Christie \& Martin, 1997, Eggins \& Slade, 2005; Scherer, Schorr \& Johnstone, 2001, Macken-Horarik, 2003, among others), Appraisal can unveil ideological meanings in discourses, in the case of the corpus, the ones related to the representations of disability.

According to Martin (2000, p. 145), "Appraisal deals with the semantic resources used to negotiate emotions, judgments and appreciations. They are resources used to expand and commit to these evaluations", being the term created to denominate all evaluative uses of language, including those in which speakers/writers adopt particular views or ideological positions.

For Martin (1992), we can locate Appraisal as an interpersonal system at the level of discourse semantics. At this level, it co-articulates interpersonal meaning with two other 
systems: negotiation and involvement. Negotiation complements Appraisal by focusing on the interactive aspects of discourse, speech function and exchange structure.

Appraisal has three subsystems for attitudinal positioning: Attitude, Engagement and Graduation, all of which dealing with evaluative interpersonal meanings of participants and processes (core concepts in the system of transitivity that represents experience ${ }^{12}$ ). Attitude relates to judgments of emotional / affective values of interactants. It is divided into three subsystems, namely Affect, Judgment and Appreciation. Martin (2000, p. 173) defines them as follows:

- Affect analyses emotions canonically in the grammatical frame: "I feel (much) 'x' ...". For example: I have a feeling of of joy / sadness.

- Judgment analyses attitudes about characters, seeking to sanction or censor behaviors canonically in the grammatical frame: "That was 'x' for him / her."

For example: I was affectionate / cruel to him.

- Appreciation analyses attitudes about texts, performances and natural phenomena, and fits them in frameworks: "I consider this " $x$ ".

For example: I consider this innovative / unimaginative.

The relevance of the use of Appraisal as a methodological framework is due to its tools to detect interpersonal meanings where ideologies can be traced as patterns in discourse. Attitude's subsystems deal with the expression of emotions by affection and its "institutionalizations" (Martin, 2000, p. 147), that is, the representation of the "other" is primarily regulated by emotions: "judgment is affection to control behavior (what we should or should not do) and appreciation is affection recontextualized to administer "tastes" (which things are worse or better)" (De Oliveira, 2008, p. 62). Ethical and moral values (rules and regulations) are achieved by judgment, while aesthetic values (criterion and quota) are achieved by appreciation. The other two subtypes of Appraisal (Engagement and Graduation) organize the force / focus of the utterance and the intersubjectivity notion by the use of hedges, boosters, etc. (Hyland, 1998) - used to construct epistemic positioning, evidentiality, intensity and other combinations. In this work, I will only focus on Attitude evaluations because emotion nurtures feelings of prejudice on disability and, therefore, it is more relevant to unveil how disability was scaffolding these ideological (mis)representations that helped to establish this type of prejudice.

Lastly, Appraisals can be inscribed and evoked -being positive or negative, they may occur separately or in combination. For Martin (2000), the inscribed type makes the attitude explicit through evaluative lexicon and syntax (epithets, relational attributes or comment adjuncts) while the evoked one occurs through lexical enrichment (for example, figurative language).

In the following section, I present the analysis of two songs that contain very informative rubrics in the manuscript identifying the targets of criticism: a judge with a limping leg (B 1303, V 908) and a knight with leprosy (B 1611, V 1144).

\section{Ideological complexes and disability}

The critical editions for this analysis is based on the collation of the manuscripts (codices in B and V songbooks) followed by lessons or interpolations proposed by: Lapa (1965) - (abbr. L.);

$12 \quad$ See Halliday (1994).

Doi: https://doi.org/10.15517/rfl.v46i2.42437 / URL: https://revistas.ucr.ac.cr/index.php/filyling/index 
Machado \& Machado (1949) - (abbr. Mdo); Lopes (2002) - (abbr. Lop.); and Braga (1878) - (abbr. Br.). Paraphrases of songs in English and critical apparatus will be found in footnotes.

The heading of the song B 1303, V 908, of Estêvão da Guarda (Table 3), brings the saying: "Esta cantiga de cima foi feita a un meestre de leis, que era manco d'ũa perna $e$ çopegava dela muito"13. It reveals a dispute based on a wordplay with the verb decaer, that is the allegory of decay (losing a dispute in court), and falling (on the floor, due to the judge's leg problem) $)^{14}$.

Table 3. Appraisal analysis of song B 1303, V 908

\begin{tabular}{|l|l|l|l|l|}
\hline & B 1303, V 908 & Appraisal & Type & INSCRIBED \\
\hline$R$ & $\begin{array}{l}\text { Esta cantiga de cima foi feita } \\
\text { a um meestre de leis, que era } \\
\text { manco d'ũa perna e çopegava } \\
\text { dela muito. }\end{array}$ & $\mathbf{J} / \mathbf{J}$ & $\begin{array}{l}\text { (-) Epithet - manco } \\
\text { (lame) } \\
\text { (-) Epithet - çopegava } \\
\text { (limped) }\end{array}$ & EVOKED \\
\hline 1 & Em preito que Dom Foam há, & $\mathbf{J}$ & & $\begin{array}{l}\text { (-) Dom Foão is the equivalent } \\
\text { of John Doe, and usually } \\
\text { hides an identity. It already } \\
\text { characterizes the target of } \\
\text { criticism negatively. }\end{array}$ \\
\hline \multirow{2}{*}{$\begin{array}{l}\text { com um meestre, há gram } \\
\text { castom; }\end{array}$} & $\mathbf{J}$ & $\begin{array}{l}\text { (-) In this case, we notice the } \\
\text { use of the retoric resourse } \\
\text { of aequivocatio. The use of } \\
\text { caston (question) or caston } \\
\text { ('caston', i.e. walking stick) } \\
\text { alludes to the judge's limping } \\
\text { condition. }\end{array}$ \\
\hline
\end{tabular}

$13 \quad$ Free Translation: "This song from above was made at a master of laws, who was lame of a leg and limped a lot on it".

14 Critical aparatus: (1) preito - judicial dispute; En L. - I opted to modernize the spelling, mainly the nasalization and the so-called 'Ramist' letters ( $<\mathrm{j}>$ and $<\mathrm{v}>$ and variations $<\mathrm{i}>,<\mathrm{y}>\mathrm{e}<\mathrm{u}>$ ); don foa $\mathrm{B}$, V; Don Joam Br.; Don Foan L.; (2) casto V, caston B - question. I admitted Lapa's punctuation com um meestre, há gram castom; Lop. suppresses the comma because he reads that the dispute is not with the master, but with someone else who is in the court, that is D. Foão has a big question with one of the masters of law; (3-5) L. reads: "and the master imagines what is very contrary to law"; (5) Mdo.: tan cox ar, o pre quamt'eu uy; (7) decaer - fall and decay; de queera $\mathrm{B}$, V; decaerá $\mathrm{Br}$;; (8) decae trisyllabic word (metre) L.; (10) demandar - look for; (12) eu ssen B; au'ida V; (12) deirito B, dereito V, direito Br. - not a metaphony. It is rather a scribe's mistake; (15) ca - because; (16) que lh'é cajom - that he will be disgraced (he will be ashamed); cajon - "disaster, discredit" L.; (17) leterados - alphabetized, people with access to formal education; (19) deato V, dereyto $\mathrm{B}$; (20) des ali - from there on.

Paraphrase: In dispute that Dom Foam has, / with a master there is [a] big question; / and the master presupposes / what is very contrary to law, for how much I see / that, if someone else does not help, / the master will fall. // But, if [he] falls, who will defend this master / without right or reason / [this master] who does not give / in his doing a help to himself / however, will he take [with him], from what I heard, / someone who sustain his right? // Because the master already understands, / if [he] falls, he will be ashamed, / among the ones who know better, (letrados - people with access to formal education) / of missing his right this way; / and who sees that, and from there on, / will take him as a bad walker. 


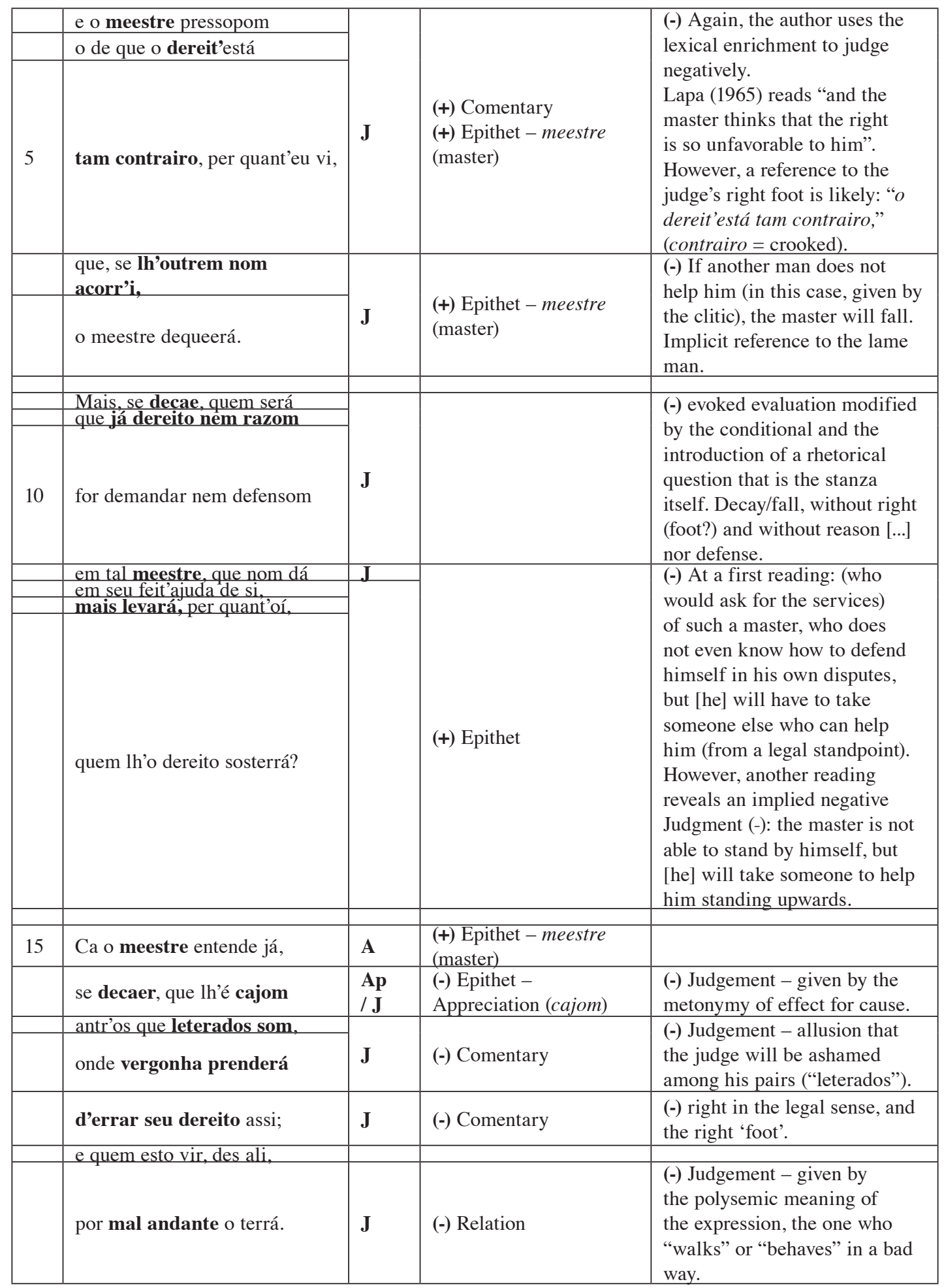

(J) Julgamento; (A) Affect; (Ap) Appreciation 
Mockery in this song is characterized by the insult and joking attitude against a person with a physical impairment, greatly by the use of the aequivocatio rhetoric resource. According to Dias (2009, p. 1), "the core of the workings of equivocation lies precisely in the play with the semantic possibilities of the word / discourse that can be understood as simultaneously true and deceitful" (our translation). This device is a fundamental pilar of Iberian satiric songs and in a lower scale in the lyrical ones. Dias assumes that equivocation

\begin{abstract}
was used as literary reason. In this field, the trick with the semantic duplicity of words and statements and the misunderstandings that may arise from the misinterpretation of polysemic words and expressions constituted a fertile field, explored in the framework of strategies and deceptive themes. Not being circumscribed to any specific textual form, equivocatio, even if in different degrees of density, thus constituted a rhetorical procedure present in much of the literary production, especially in the medieval period (Dias, 2009, p. 1, our translation).
\end{abstract}

A major theme of this song, disability, was poorly documented in the Middle Ages (Metzler, 2006), and very little was written or recorded about a general disabled community at the time. Hence, poetry gives us information beyond a historic note. It is noticeable in this song a formed ideological paradigm of stereotyping disabled persons, in this case, a lame man. Piza (1991, pp. 17-21), analyzing studies of Amaral (1989), presents three predominant images of nowadays for the person with any type of disability:

$1-[\ldots]$, they appear as those (especially the human characters) who persevere in a discourse of resignation,
sometimes able to claim the "normality" award, miraculously achieved; 2 - the different / disabled depends on the
interposition of a "normal" between himself / herself and the world, in order to make his / her existence viable; 3 -
The "happy different" is the exiled different. A full existence is only possible outside the universe of "normality"
(Piza, 1991, pp. 17-18).

Estêvão da Guarda's medieval song adds up some considerations over modern-time aspects raised by Piza (1991): (a) in this song, the character is not a fictional product, except for a probable exaggerated representation, which is typical of the genre; (b) at the time of the Galician-Portuguese songs, it doesn't seem there was intention to establish any 'normality' label to those who carried any kind of impairment; and (c) the author had no purpose of assuming a modalizing behavior to criticize. On the contrary, rhetoric strategies, like the wordplay, often served only to adequate the text to the sirventês genre and intensify laughter. In this sense, this song portrays a medieval society not in search of any kind of "social reparation"; the social chasm between concepts of "normal" and "abnormal" was otherwise reinforced in that context.

The Spread of Christianity in Iberian Peninsula had antagonistic effects. Christian doctrine nurtured values of human charity and brotherly love. On the other hand, dogmas brought a kind of segregationist ideology (see Griffith, 2012). For example, The Order of Friars Minor helped in the indoctrination of the remission of sins by self-denial and loving your fellow man, especially the weakened, sick, and persons with special needs. Rome began supporting initiatives in this direction (Silva, 1987). In the meantime, as Middle Ages progressed, historical documents testify an increasing association of disabilities with magic, witchcraft, and mysticism, a story that precluded other stories of that people. According to Silva (1987, p. 45), at the time, "physical disabilities become strongly associated with demonic forces and the Catholic Church established "normality standards". Rejection and persecution increased during the Inquisition. Then, several institutions worked against heretics (or other offenders against canon law) within the judicial system of the Roman Catholic Church, among them, some people in disability condition who, being accused of witchcraft, came to survive in complete marginality. 
Although historical data can be easily recovered from legal documents, literature brings to memory intangible aspects of a greater social barrier, a paradigm built on ideological presuppositions that is hard to overcome. Still in the 21st century, we observe remnants of segregation, prejudice, racism and eugenics consubstantiated in ideological complexes in literary tradition. For Guerra (2006), we live a moment of a special ethical conflict, and we witness discussions of segregation resurfacing with great intensity.

Below, the analysis of the song B 1611, V 1144 (Table 4) ${ }^{15}$, the only production of Estêvão Fernandes Barreto that came to us. Interestingly, the mocking target is a leper knight, and the nobiliary books ${ }^{16}$ tells us that one of the author's seven children was also a leper.

15 Critical aparatus: (Rubric) soer - having the habit of; gafaria - hospital for people with leprosy; rubric is only complete in B; (1) Ss teneans B, Steueans V, [Don] L. - there is some disagreement with Lapa's reading that identifies the target as D. Estevão Anes, chancellor of King D. Afonso III of Portugal. Although inaccurate, Oliveira's (1993b) identity analysis of this knight seems to be more precise. He offers two possibilities: (a) D. Estêvão Anes Brochardo, archdeacon of Santarém between 1293 and 1298, courtier of D. Dinis from 1296, and later becoming bishop of Coimbra. He would be cousin of Fernão Dade, mentioned in the song; or (b) Estêvão Anes de Paiva, who appears as a witness, alongside Fernão Dade, in a donation to D. Dinis and also signed by the troubadour. This document places the two characters in the same time-space context. In addition, there is the consideration that Estêvão Anes de Paiva was the cousin of Rui Pais de Paiva, also mentioned in the second verse of the song, being both grandsons of the prolific troubadour João Soares de Paiva. Considering that Oliveira's interpretation (1993b) is correct for Fernão Dade's testament date (1295), and having been this troubadour in Santarém the previous year, this song must have been composed around this date; (2) paciez V, paaez B - Pizarro (1999, pp. 424 and 426) points out to the possibility of this character being Rui Pais Bugalho, "that the Livro de linhagens do Conde don Pedro tells us to have been a good knight and courtier of King D. Dinis (Livro de linhagens do Conde don Pedro, p. 71B3)". I agree with Oliveira's interpretation (1993b) due to context and documents (i.e. Rui Pais de Paiva); (4) triscare V, trijdade B, trindade Br. (5) Fernam Dade - according to Pizarro (1999), he is the son of Martim Dade, a well-known mayor (alcaide) of Santarém. (6) ciada - trap; (8) soía - he used to, reference to a pilgrimage towards city of Santarém he used to be part of; (10) seer mester - be convenient; (14) alo B, V - ali or lá (adv. there), alo is still used in the Galician language; (15) $u$ - where.

Paraphrase: Estêvam Eanes, by God's command / to Roi Paaes, soon this day, / [that] if you want to go to Santa Maria / don't go through Triindade, / because someone told me that you have Fernam Dade / setting a trap for you to gafaria (hospital for patients with leprosy) // And if you want to make this pilgrimage, / as you used to do, / another path you should take though / because the Triindade one is not convenient; / because someone says that Fernam Dade wants you / setting a trap for you to gafaria // And every [year] that he comes to Santarém, / always makes the pilgrimage there; / and [the path] of Trindade, you used to go through there, / [I] warn you, take good care of yourself, / because someone says that Fernam Dade has / [to] a trap set for you to gafaria.

16 Livro de linhagens do Conde don Pedro (see Mattoso, 1980) is a compilation of lineage data from the previous Livros de Linhagens, and a revised version of the Navarrese Liber regum and the lost Crónica Portuguesa de Espanha e Portugal. 
Table 4. Appraisal analysis of song B 1611, V 1144

\begin{tabular}{|c|c|c|c|c|}
\hline & B 1611, V 1144 & \multicolumn{3}{|c|}{ Appraisal } \\
\hline & & Type & INSCRIBED & EVOKED \\
\hline$R$ & $\begin{array}{l}\text { Esta cantiga de cima fez } \\
\text { Stevam Fernándiz Barreto a } \\
\text { um cavaleiro que era gafo e } \\
\text { morava em Santarém; e soem a } \\
\text { ir em romaria a Santa Maria; } \\
\text { aa mão dereita do caminho está } \\
\text { logo a Triindade, e estava logo a } \\
\text { gafaria a par dela. }\end{array}$ & $\mathbf{J}$ & $\begin{array}{l}\text { (-) Epithet } \\
\text { gafo (leper) } \\
\text { (-) Epithet } \\
\text { gafaria } \\
\text { (hospital for } \\
\text { patients with } \\
\text { leprosy) }\end{array}$ & $\begin{array}{l}\text { (-) Lapa (1965: 207) thinks this rubric } \\
\text { "offers its doubts". He proposes an } \\
\text { interpretation though: "it is a leper } \\
\text { knight, who was escaping to be put } \\
\text { in the Gafaria, and of a certain } \\
\text { Fernão Dade, who looked for the } \\
\text { best occasion to get him there". In } \\
\text { fact, the anecdote itself represents a } \\
\text { negative evoked evaluation given by } \\
\text { the runaway attitude. }\end{array}$ \\
\hline \multirow[t]{4}{*}{1} & $\begin{array}{l}\text { [E]stêv[am] Eanes, por Deus } \\
\text { mandade }\end{array}$ & & & \\
\hline & a Roi Paaes, logo este dia, & & & \\
\hline & [que] se quiser ir a Santa Maria & & & \multirow{4}{*}{$\begin{array}{l}\text { (-) Evoked evaluation is in the } \\
\text { background meaning given by the } \\
\text { figure of speech. According to Lapa } \\
\text { (1965, p. 207), "the allusion seems } \\
\text { clear: Rui Pais, being a leper, should } \\
\text { go to the Gafaria, where Fernão Dade, } \\
\text { perhaps a King's official, wanted to } \\
\text { force him, setting a trap for him". }\end{array}$} \\
\hline & que se nom vaa pela Triindade, & & & \\
\hline \multirow[t]{5}{*}{5} & $\begin{array}{l}\text { ca mi dizem que lhe tem Fernam } \\
\text { Dade }\end{array}$ & & & \\
\hline & $\begin{array}{l}\text { ciada feita pela } \\
\text { gafaria. }\end{array}$ & $\mathbf{J}$ & $\begin{array}{l}\text { (-) Epithet } \\
\text { gafaria }\end{array}$ & \\
\hline & Se a romaria fazer quiser, & & & \\
\hline & como a sempre fazer [el] soía, & & & \\
\hline & outro caminho cate todavia; & & & \\
\hline \multirow[t]{5}{*}{10} & $\begin{array}{l}\text { ca o da Triindade nom lh’é } \\
\text { mester; }\end{array}$ & & \multirow{3}{*}{$\begin{array}{l}\text { (-) Epithet } \\
\text { gafaria }\end{array}$} & \multirow{3}{*}{ (-) Same as the previous refrain. } \\
\hline & $\begin{array}{l}\text { ca dizem que Fernam Dade lhe } \\
\text { quer }\end{array}$ & \multirow[t]{2}{*}{$\mathbf{J}$} & & \\
\hline & meter ciada pela gafaria. & & & \\
\hline & E cada que el vem a Santarém, & & & \\
\hline & sempre aló vai fazer romaria; & & & \\
\hline \multirow[t]{4}{*}{15} & e da Triindade, per u soía & & & \\
\hline & $\begin{array}{l}\text { d'ir, mandade que se guard'el } \\
\text { mui bem, }\end{array}$ & $\mathbf{J}$ & & $\begin{array}{l}(-) \text { the warning advice implies a } \\
\text { practice of persecution against lepers. } \\
\text { At least the noble ones were taken to } \\
\text { treatment. }\end{array}$ \\
\hline & $\begin{array}{l}\text { ca dizem que Fernam Dade lhe } \\
\text { tem }\end{array}$ & \multirow[t]{2}{*}{$\mathbf{J}$} & \multirow{2}{*}{$\begin{array}{l}\text { (-) Epithet } \\
\text { gafaria }\end{array}$} & \multirow[t]{2}{*}{ (-) same as previous. } \\
\hline & ciada feita pela gafaria. & & & \\
\hline
\end{tabular}

(J) Julgamento; (A) Affect; (Ap) Appreciation

In this song, humor is based on stereotyping a leper. In truth, humor is one of the silent ways in which prejudice and segregation sets in. For Goffman (1988, p. 67), "caricatures, jokes [...] reveal, in a less serious way, the weaknesses of a stereotypical member of a category". Respectively, a stereotyped caricature of a disabled person reveals a semantic ideological ambivalence: normality of a conceived abnormality (alterity from the big Other, see Goodley, 2016, p. 79). For Estêvão Fernandes Barreto, the fact that his son had the same condition (leprosy) implies in what Goffman (1988, p. 67) refers as "self-alienation". 
In the song, it is possible to notice the use of evoked Judgement appraisals sanctioning behavior implicitly. Disconsideration of (or distinction towards) a being based on the group, class, or category to which he/she is perceived to belong, when based on disability causes, results on a type of prejudicial discrimination. From that, stereotypes are nurtured by the insistence ("single story") of this type of representation.

Stereotypes of disabilities, when standing by humor, rapidly diffuses into society, even when there seems to be no reason or logic for that. For example, homosexuality was regularly associated to a disability or disease ${ }^{17}$ in Middle Ages. In this context, it could be understood as an intersectional factor in the appreciation of the body and as a disease, oftentimes linked by troubadours to some sort of spiritual issue or by influence of the Demo - as referred by them. This biased attitude has continued for centuries in Western literature, having in previous literary movements some well-established paradigms thereof.

Nonetheless, a brief digression from this specific song of Estêvão Fernandes Barreto focusing leprosy is now justified because Table 2 brings examples of a cycle of satires (for example, V 1014 bis - João Soares Coelho) mocking another D. Estevam ${ }^{18}$, not confounded with Estêvão Fernandes Barreto. This anthology has arguments centered on a supposed homosexuality and vision problems of D. Estevam while aligning them both as "health conditions" which perhaps, most amusingly, denotes an ideological stance framing homosexuality as a type of disability. In one of his songs, for example, the troubadour Rui Queimado says that, because of his sin, D. Estevam listens attentively to the sermon in the church, because he does not see. At another point, he treats as hypocrisy the contrast between D. Estevam "in-church behavior" and his "nocturnal activities", as if blindness were a scam for his "homosexual practices". Then, the troubadour recriminates D. Estevam: "Confonda Deus quem cego chama quem/ assi ouve come vólo sarmom," B 1386, V $995^{19}$.

Although other aspects of human behavior were also seen as disabilities by the stand of the big Other "normativity" in Galician-Portuguese songs, the exact extent of the ideological complexes on behavioral standards in early works of literature is still somehow disputed and obscure. At the same time, influences and consequences are undeniable:

17 There are forty Galician-Portuguese songs where the theme is identified (see Lopes, 2002), from various troubadours, namely, Estêvão da Guarda, João Baveca, Airas Veaz, Airas Peres Vuitorom, Pero da Ponte, D. Dinis, João Vasques de Talaveira, Rui Queimado, João Soares Coelho, Mem Rodrigues Tenoiro, Pedro Amigo de Sevilha, Pero Garcia Burgalês, João Garcia de Guilhade, Estêvão Faião, Afonso Anes do Cotom, Afonso Mendes de Besteiros, Gonçalo Anes do Vinhal, Vasco Peres Pardal, and Pero Viviães.

18 Vasconcelos (1911) identifies this D. Estevam as D. Estêvão Anes, the powerful chancellor of King Afonso III. In her reading, the philologist weighs on the probable date of this cycle of songs. The text of the songs reveals an intimate relationship between the Bolognese (King Afonso III) and the songs' target. Oliveira (1993a) confirms the connection between Estêvão Anes and Afonso III, however, he does not propose any alternative identity for this D. Estevam, whose identity remains unknown. The group of Alfonsine troubadours who censured D. Estevam is varied, among them, João Soares Coelho ("Dom Estêvam fez sa partiçom,", "Quem diz de Dom 'Stêvam que nom vê bem,", and "Dom Estêvam, que Lhi nom gradecedes,"), Mem Rodrigues Tenoiro ("Dom Estêvam achei noutro dia,"), Airas Peres Vuitorom ("Dom Estêvam diz que desamor,", "Dom Estêvam, tam de mal talam,", and "Dom Estêvam, eu eiri comi,").

19 Paraphrase: Punish God who calls [himself] blind [someone] who / hears the sermon likewise. 
tendency to simplify things has led us to dismiss some of the presumed characteristics of stereotypes and prejudice that were essential for early conceptualizations [...] which include imprecision, negativity and supergeneralizations [...]. Stereotypes are problematic because they are negative, inaccurate, and unfair - they would simply be part of the study of a person's perception (Nelson, 2009, p. 4).

For Czopp (2008), even when positive, stereotypes are essentially negative or bring negative consequences. Literature, particularly when it comes to representing disabilities, resurges in modernity as a symbol of resistance and paradigm shift. Jauss (1967, p. 3) proposes that the renewal of literary history requires the "elimination of the prejudices from the historical objectivism and traditional aesthetic foundation of production and representation" to an "author's reflective criticism".

Galician-Portuguese songs, by its part, compounded a testimony of then-consolidated paradigms about mobility, visual and hearing impairment as well as disability through various diseases or physical-behavioral aspects. Appraisal, as a functional linguistic model to deal with the semantics of evaluation, evinced that judgement-type evoked appraisals were the most constant encoding evaluation of disability.

In these songs, troubadours were routinely sanctioning disabled characters negatively. In addition, the greater use of implicit evaluation (evoked) through humor maximized the persuasive power of the songs by despising characters. A process of "self-alienation" was also demonstrated by the troubadours which factored the losing of objectivity and realness in discourses. As of then, patterns of normality were mainly conceived from Catholicism and soteriological doctrine, which bullied and segregated disabled persons as representations of 'abnormal' and 'inferior' (see Le Goff, 1986) in Galician-Portuguese literature.

\section{Concluding remarks}

Appraisal analyses in this article revealed discrimination and stereotypes sustained by ideological complexes. Prejudice on disability, if considered as "any attitude, emotion or behaviour towards members of a group, which directly or indirectly implies some negativity or antipathy towards that group" (Brown, 2011, p. 27), developed strongly into the context of the Galician-Portuguese literature, for what from the beginning of our literary tradition. The semantics of evaluation demonstrated how negatively the characters' aspects of disabilities were portrayed in the corpus.

In regard to the questions proposed in this study, analyses showed troubadours manifesting an ideology of misrepresentation anchoring criticism of disabled characters. Data was insufficient to rectify or ratify the consolidation, strengthening or spread of such representations from Galician-Portuguese literature on. As Metzler (2006, p. 6) reasons, our culture's assumptions may blur our judgement of disability in that context. However, this study managed to evince a clear pattern of misrepresentations that is also noticeable in later Western literary manifestations of prejudice taprooted on ideologies.

I conclude by making reference to Werneck (1997, p. 139), who believes prejudice is based on the "lack of formation", that is, a "silent, slow, progressive and cumulative process of inadequate notions about taboo themes". In essence, disability is at the heart of these taboo themes which makes the findings of mockery on disability in Galician-Portuguese 
literature valuable to framing these ideological complexes as results of slow, progressive, silent, cumulative processes that also took place in the history of literature. To sum up, understanding such ideologies, in the past and in the modern society, is a great step to promote critical thinking of readers and writers into a necessary mission for human development.

\section{Bibliography}

Adichie, C. N. (2009). The danger of a single story. TED Conferences. [Video file]. Retrieved from https://www.ted.com/talks/chimamanda_adichie_the_danger_of_a_single_story

Albrecht, G. L., Seelman, K. D. \& Bury, M. (Eds.). (2001). Handbook of disability studies. London: Sage Publications.

Althusser, L. ([1970] 2009). Ideology and ideological state apparatuses (notes towards an investigation). In A. Sharma \& A. Gupta (Eds.), The anthropology of the state: a reader (pp. 86-111). New Jersey: John Wiley \& Sons.

Amaral, L. A. (1989). Deficiência física e integração social. Revista Integração, 2(4), 36-8.

Banks, D. (2009). The position of ideology in a systemic functional model. Word, 60(1), 39-63.

Braga, J. T. F. (1878). O cancioneiro portuguez da Vaticana. Florida: Library of Alexandria.

Brown, R. (2011). Prejudice: Its social psychology. New Jersey: John Wiley \& Sons.

Cambridge (n. d.). Termo: impairment. Cambridge Org. Dicionário online. Retrieved from https://dictionary.cambridge.org/pt/dicionario/ingles/impairment

Campbell, F. K. (2008). Refusing able (ness): A preliminary conversation about ableism. M/C Journal, 11(3). Retrieved from http://journal.media-culture.org.au/index.php/ mcjournal/article/view/46

Campbell, F. K. (2009). Contours of ableism: Territories, objects, disability and desire. London: Palgrave Macmillan.

Ceschin, O. H. L. (1998). A educação do cavaleiro na expressão do trovador. Revista Comunicações e Artes, 21(34), 36-55.

Ceschin, O. H. L. (2004). Poesia e história nos cancioneiros medievais: o cancioneiro do infanção. Humanitas, FFLCH/USP.

Christie, F. \& Martin, J. R. (1997). Genre and institutions. London: Continuum.

Comber, A. E. (2016). A Medieval King 'Disabled' by an Early Modern Construct: A Contextual Examination of Richard III. In J. R. Eyler (Ed.), Disability in the Middle Ages (pp. 195-220). Routledge.

Czopp, A. M. (2008). When is a compliment not a compliment? Evaluating expressions of positive stereotypes. Journal of Experimental Social Psychology, 44(2), 413-420.

De Oliveira, U. T. V. (2008). O fenhedor e o precador nas cantigas líricas galego-portuguesas de D. Dinis: uma perspectiva sistêmico-funcional. (Master's Thesis). Pontifícia Universidade Católica. Retrieved from https://leto.pucsp.br/handle/handle/13937

Dias, I. D. B. (2009). A equivocatio na narrativa historiográfica ibérica dos sécs. XIII e XIV. e-Spania. Revue interdisciplinaire d'études hispaniques médiévales et modernes, (8), 1-14. 
Eggins, S. \& Slade, D. (2005). Analysing casual conversation. Equinox Publishing Ltd.

Fanon, F. (1993). Black skins, white masks. (3 ed.). London: Pluto Press.

Figueira, E. (2000). As pessoas com deficiências no contexto da literatura infanto-juvenil e didática. Mimesis, 21(1), 39-52.

Fowler, R. (2013). Language in the News: Discourse and Ideology in the Press. London: Routledge.

Fuoli, M. (2015). Combining APPRAISAL and CDA in the analysis of corporate discourse. In 42nd International Systemic Functional Congress. Aachen, Germany.

Goffman, E. (1988). Estigma-Notas sobre a Manipulação Deteriorada. Rio de Janeiro: Editora Guanabara.

Goodley, D. (2016). Disability studies: An interdisciplinary introduction. Newbury: Sage.

Griffith, S. H. (2012). The Church in the Shadow of the Mosque: Christians and Muslims in the World of Islam. Princeton University Press.

Guerra, A. T. M. (2006). Do holocausto nazista à nova eugenia no século XXI. Ciência $e$ Cultura, 58(1), 4-5.

Halliday, M. A. K. (1994). An Introduction to Functional Grammar. (2 ed.). London: Edward Arnold.

Herculano, A. (2014). História de Portugal. Lisbon: Ediçoes Vercial.

Hyland, K. (1998). Hedging in scientific research articles. Amsterdam: John Benjamins.

Hume, M. A. S. (1905). Spanish influence on English literature. London: E. Nash.

Iedema, R., Feez, S. \& White, P. R. (1994). Media literacy. Sydney: Disadvantaged schools program. Sydney: NSW Department of school education.

Jauss, H. R. (1967). Literaturgeschichte als Provokation der Literaturwissenschaft. Frankfurt: Frankfurt-on-Main.

Kiple, K. F. (1999). Epidemics and History: Disease, Power, and Imperialism. Journal of Interdisciplinary History, 30(1), 104-105.

Lanciani, G., Tavani, G. \& Gaspar, S. (1995). As cantigas de escarnio. Xerais De Galicia Edicions.

Lapa, M. R. (Ed.). (1965). Cantigas D'escarnho e de mal dizer. Lisboa: Editorial Galaxia.

Lawson, M. D. (2019). Children of a One-Eyed God: Impairment in the Myth and Memory of Medieval Scandinavia. (Master's Thesis). East Tennessee State University. Retrieved from https://dc.etsu.edu/etd/index.2.html

Le Goff, J. (1982). Time, work, and culture in the Middle Ages. University of Chicago Press.

Le Goff, J. (1986). A nova história. Paris: Edições 70.

Li, J. (2010). Transitivity and lexical cohesion: Press representations of a political disaster and its actors. Journal of Pragmatics, 42(12), 3444-3458.

Lopes, G. V. (1998). A sátira nos cancioneiros medievais galego-portugueses: sátira, zombaria e circunstância no Cancioneiro Geral de Garcia de Resende. Estampa. 
Lopes, G. V. (2002). Cantigas de Escárnio e Maldizer dos trovadores e jograis galegoportugueses. Lisbon: Editorial Estampa.

Machado, J. P. \& Machado, E. P. (1949). Cancioneiro da Biblioteca Nacional: antigo ColocciBrancuti. Lisbon: Biblioteca Nacional de Portugal.

Macken-Horarik, M. (2003). Appraisal and the special instructiveness of narrative. TEXT-THE HAGUE THEN AMSTERDAM THEN BERLIN, 23(2), 285-312.

Major, R. H. (1954). A history of medicine. Illinois: Charles C. Thomas Publisher.

Martin, J. R. (1992). English text: System and structure. John Benjamins Publishing.

Martin, J. R. (2000). Beyond exchange: Appraisal systems in English. Evaluation in text: Authorial stance and the construction of discourse. Oxford: Oxford University Press.

Mattoso, J. P. (1980). Livro de Linhagens do conde D. Pedro. Lisbon: Academia das ciências de Lisboa.

Metzler, I. (2006). Disability in medieval Europe: Thinking about physical impairment in the High Middle Ages, c. 1100-c. 1400. London: Routledge.

Miguélez-Carballeira, H. (Ed.). (2014). A Companion to Galician Culture. London: Boydell \& Brewer Ltd.

Nirenberg, D. (2015). Communities of violence: Persecution of minorities in the middle agesupdated edition. Princeton University Press.

Nelson, T. D. (Ed.). (2009). Handbook of prejudice, stereotyping, and discrimination. Amsterdam: Psychology Press.

Oliveira, A. R. (1987). A cultura trovadoresca no ocidente peninsular: trovadores e jograis galegos. Biblos LXIII.

Oliveira, A. R. (1993a). Estêvão da Guarda, Dicionário da Literatura Medieval Galega e Portuguesa. (Lanciani, G. \& Tavani, G., Eds.) Lisbon: Editorial Caminho.

Oliveira, A. R. (1993b): Estevan Fernandiz Barreto, in Dicionário da Literatura Medieval Galega e Portuguesa. (Lanciani, G. \& Tavani, G., Eds.). Lisbon: Editorial Caminho.

Piza, E. P. (1991). Imagens da deficiência na literatura infanto-juvenil: vícios e usos. In M. Cruz (Ed.), O deficiente e as diferenças na leitura infantil e juvenil: bibliografia (pp. 17-21). São Paulo: Secretaria Municipal de Cultura de São Paulo - Seção de Bibliografia e Documentação.

Pizarro, J. A. (1999). Linhagens medievais portuguesas: genealogias e estratégias 1279-1325. (vol. 2). Porto: Centro de Estudos de Genealogia, Heráldica e História da Família da Universidade Moderna.

Reeve, C. D. C. (1998). Aristotle: Politics. Indianapolis: Hackett.

Richards, P. (2000). The medieval leper and his northern heirs. London: Boydell \& Brewer.

Rodríguez, B. (2017). Chaucer's Hidden Iberian Influence. University of Notre Dame. Retrieved from https://sites.nd.edu/manuscript-studies/2017/03/08/chaucers-hiddeniberian-influence/ 
Sansone, L. y Furtado, C. A. (2014). Dicionário crítico das ciências sociais dos países de fala oficial portuguesa. Salvador: EDUFBA.

Scherer, K. R., Schorr, A. \& Johnstone, T. (Ed.). (2001). Appraisal processes in emotion: Theory, methods, research. Oxford: Oxford University Press.

Sequeira, F. J. M. (1959). Gramática histórica da línqua portuguesa. Lisbon: F. Franco.

Silva, O. M. (1987). A epopéia ignorada: a pessoa deficiente na história do mundo de ontem $e$ de hoje. São Paulo: Centro São Camilo de Desenvolvimento em Administração da Saúde.

Spina, S. (1997). A cultura literária medieval: uma introdução. Atelie Editorial.

Tiron, R. (1848). Histoire et costumes des ordres religieux, civils et militaires. (Vol. 1). Paris: Librairie Ethnographique.

Van Dijk, T. A. (1998). Ideology: A multidisciplinary approach. Newbury: Sage.

Van Dijk, T. A. (2002). Political discourse and ideology. In C. U. Lorda y M. Ribas (Orgs.), Anàlisi del discurs polític: Producció, mediació i recepció (pp. 15-34). Barcelona: Universitat Pompeu Fabra, Institut Universitari de Lingüística Aplicada (IULA).

Van Dijk, T. A. (2006). Discourse and manipulation. Discourse \& Society, 17(3), 359-383.

Vasconcelos, C. M. (1911). Lições de filologia portuguesa. Lisbon: Revista de Portugal.

Vivas, D. \& Oliveira-Leitão, A. (2008). A presença islâmica no Alentejo Litoral. Uma abordagem à luz da toponímia. $1 .^{\circ}$ Encontro de História do Alentejo Litoral, 220-229.

Wells, S. (2016). The exemplary blindness of Francis of Assisi. In J. R. Eyler (Ed.), Disability in the Middle Ages (pp. 79-92). London: Routledge.

Werneck, C. (1997). Ninguém será mais bonzinho na sociedade inclusiva. Rio de Janeiro: WVA.

Yeager, R. F. (2007). Chaucer Translates the Matter of Spain. In M. Bullón-Fernandez (Ed.), England and Iberia in the Middle Ages, 12th-15th Century: Cultural, Literary, and Political Exchanges (pp. 189-215). New York: Palgrave Macmillan. 
